\title{
PEMBIASAAN ORANG TUA DALAM MENERAPKAN TOILET TRAINING (TT) PADA ANAK USIA 2 -3 TAHUN DI PONTIANAK Oleh : Halida ${ }^{1}$ dan Dita Habsari ${ }^{2}$
}

\begin{abstract}
ABSTRAK
Anak balita dapat diartikan sebagai kelompok anak yang berada dalam proses pertumbuhan dan perkembangan yang sangat pesat dan bersifat unik. Itu artinya anak tersebut memiliki proses pertumbuhan dan perkembangan fisik (koordinasi motorik halus dan motorik kasar), kecerdasan (daya pikir, daya cipta, kecerdasan emosi, kecerdasan spiritual), sosio-emosional (sikap dan prilaku serta agama), bahasa dan komunikasi yang khusus sesuai dengan tingkat pertumbuhan dan perkembangan yang dilaluinya. Anak usia 2-3 merupakan salah satu bagian yang sangat peka terhadap penyerapan terhadap lingkungan. Toilet training merupakan hal yang sangat urgen untuk dilatih sehingga menjadi pembiasaan yang positif baik untuk orangtuanya maupun untuk anak itu sendiri.

Kebiasaan yang salah dan keliru dalam mengontrol BAB dan BAK akan menimbulkan hal-hal yang buruk pada anak dimasa mendatang. Hal ini menyebabkan konsep hidup anak kurang baik, manja, kurang mandiri, kurang bisa mengontrol emosi, dan yang terpenting adalah dimana nanti pada saatnya anak akan mengalami masalah psikologi, anak akan merasa berbeda dan tidak dapat secara mandiri mengontrol buang air besar dan buang air kecil. Dari hasil penelitian yang dilakukan pada orangtua yang mempunyai anak usia 2-3 tahun di Pontianak dapat dilihat hasilnya bahwa pengetahuan orangtua tentang penerapan Toilet Traning (TT) yang benar sebesar 62,55\%. Tingkat keberhasilan orangtua dalam menerapkan toilet training sebesar $65,85 \%$ serta faktor-faktor yang menjadi penyebab gagalnya anak melakukan toilet traning. Hal ini disebabkan karena orangtua kurang mempunyai pengetahuan dan wawasan yang luas tentang perkembangan anak sehingga anak tidak dilatih sesuai usia dan kemampuan anak tentang toilet training, orangtua kurang sabar, orangtua kurang konsekwen dan orangtua kurang disiplin dalam menerapkan toilet training yang benar pada anak.
\end{abstract}

${ }^{1}$ Halida : adalah Dosen Jurusan Ilmu Pendidikan FKIP Untan

${ }^{2}$ Dita Habsari : adalah Mahasiswa Program S1 PAUD FKIP 


\section{PENDAHULUAN}

Periode penting dalam tumbuh kembang anak adalah masa balita, dimana pada masa ini pertumbuhan dasar yang akan mempengaruhi dan menentukan perkembangan anak selanjutnya. Pada masa balita ini perkembangan kemampuan berbahasa, kreativitas, kesadaran sosial, emosional dan intelegensia berjalan sangat cepat dan merupakan landasan perkembangan berikutnya. Di Indonesia diperkirakan jumlah balita mencapai $30 \%$ dari 250 juta jiwa penduduk Indonesia, dan menurut Survey Kesehatan Rumah Tangga (SKRT) Nasional diperkirakan jumlah balita yang susah mengontrol BAB dan BAK (ngompol) di usia sampai prasekolah mencapai 75 juta anak. Fenomena ini dipicu karena banyak hal, pengetahuan ibu yang kurang tentang cara melatih BAB dan BAK, pemakaian popok sekali pakai, hadirnya saudara baru dan masih banyak lainnya).

Konsep Toilet Training (TT) memang belum banyak dipahami dikalangan masyarakat, hal ini disebabkan karena informasi terkait tentang toilet training tidak dikenalkan secara umum dimasyarakat sedangkan fenomena yang terjadi di masyarakat akibat dari konsep Toilet Training yang tidak diajarkan secara benar atau kurang tepat sangatlah tidak sedikit hal ini karena dampak negative yang ditimbulkan tidaklah dapat dilihat secara langsung, ini yang menyebabkan konsep toilet training dipandang tidaklah penting dalam tahap perkembangan anak balita. Perkembangan pada usia balita merupakan perubahan dari fase percaya tidak percaya menjadi fase otonomi ditunjukkan dengan sikap kemandirian yang semakin meluas pada masa ini anak dapat mengontrol bagian tubuhnya, kemampuan dalam berbahasa meningkat, dan pada fase ini juga berada pada fase anal dimana anak mulai mampu untuk mengontrol buang air besar dan buang air kecil. Tumbuh kembang anak serta kemampuan mereka dapat diindentifikasi lebih awal, yang selanjutnya dapat dikembangkan. Berbekal pemahaman tentang perkembangan anak balita maka orang tua atau orang dewasa lainnya dapat mengetahui titik terpenting untuk pengembangannyya, dengan menitik beratkan pada masa belajar anak.

Lima tahun pertama kehidupan anak merupakan letak dasar bagi terpenuhinya segala kebutuhan fisik, maupun psikis di awal perkembangannya, diramalkan akan dapat melaksanakan tugas-tugas perkembangan selanjutnya. Pada masa ini juga disebut-sebut sebagai masa 
keemasan (golden age) dalam perkembangan seorang anak, sebab diusia ini anak mengalami lompatan kemajuan yang menakjubkan (Hurlock, 2003).

Pengetahuan tentang Toilet Training sangat penting untuk dimiliki oleh seorang ibu. Hal ini akan berpengaruh pada penerapan toilet training pada anak. Ibu yang mempunyai tingkat pengetahuan yang baik berarti mempunyai pemahaman yang baik tentang manfaat dan dampak Toilet Training, sehingga ibu akan mempunyai sikap yang positif terhadap konsep toilet training. Sikap merupakan kecenderungan ibu untuk bertindak atau berperilaku.

\section{Rumusan Masalah}

Berdasarkan rumusan masalah diatas maka masalah umum dalam penelitian ini adalah "Bagaimanakah Pembiasaan Orang Tua dalam Menerapkan Toilet Training (TT) pada Anak Usia 2-3 Tahun di Pontianak?".

Adapun sub-sub masalah dalam penelitian ini adalah :

1. Apakah orangtua mempunyai pengetahuan tentang pelaksanaan toilet training yang benar pada anaknya?

2. Seberapa besar tingkat keberhasilan orang tua dalam menerapkan toilet training pada anak usia 2-3 tahun di Pontianak ?

3. Faktor-faktor apa saja yang menyebabkan orangtua kurang membiasakan anak untuk toilet training pada anak usia 2-3 tahun di Pontianak?

\section{Tujuan}

Tujuan umum dilakukannya penelitian ini adalah "Untuk Mengetahui Pembiasaan Orang Tua dalam Menerapkan Toilet Training pada Anak Usia 2 -3 tahun di Pontianak".

Adapun tujuan khusus dalam penelitian ini adalah :

1. Mengetahui pengetahuan orangtua dalam melaksanakan toilet training yang benar pada anaknya.

2. Mengetahui tingkat keberhasilan orang tua dalam menerapkan toilet training pada anak usia 2-3 tahun di Pontianak?.

3. Memngetahui faktor-faktor yang menyebabkan orangtua kurang melatih membiasakan anak untuk toilet training pada anak usia 2-3 tahun di Pontianak?. 


\section{TINJAUAN PUSTAKA}

\section{Pengertian Toilet Training}

Ada banyak hal yang menyertai pertumbuhan seorang anak terutama dalam tiga tahun pertama kehidupan. Pertumbuhan dan perkembangan berlangsung sangat pesat pada lima tahu pertama kehidupan anak. Proses ini mencakup perkembangan kemampuan kognitif dan perilaku. Seringkali dalam membesarkan anak, para orangtua terjebak dalam pola pikir untuk menyelesaikan semua pendidikan anak secepat mungkin, baik itu berbicara, berjalan, bahkan menggunakan toilet. Sebenarnya semua hal tersebut merupakan langkah perkembangan normal yang prosesnya tidak perlu terburu-buru (Gilbert, 2003).

Toilet Training (mengajarkan anak ke toilet) adalah cara anak untuk mengontrol kebiasaan membuang hajatnya di tempat yang semestinya, sehingga tidak sembarangan. Buang air besar (BAB) dan air kecil (BAK) bukanlah suatu masalah besar, jika orangtua dari kecil telah melatih dan membiasakan anak ketika mau buang hajatnya. Bagi anak balita, mandiri untuk bisa BAB dan BAK hal yang patut diacungi jempol. Minimal, anak bisa memberi tanda-tanda saat akan BAK atau BAB. Bagaimana melatih kemandirian anak untuk bisa BAB atau BAK. Mengajari anak untuk menggunakan toilet membutuhkan waktu, pengertian, konsekwensi dan kesabaran.

Menyesuaikan pemberian latihan dengan usia anak adalah hal yang wajib diperhatikan. Demikian pula dengan toilet training, di mana orangtua/pengasuh mengajarkan cara-cara buang air kecil (BAK) dan buang air besar (BAB) di toilet pada anak. Selain itu perlu diperhatikan teknik pelaksanaan dan sikap orangtua. Berhasil atau tidaknya fase toilet training ini sangat berpengaruh terhadap perkembangan selanjutnya dari seorang anak yaitu kemampuan mengendalikan perkemihan dan pencernaan (Gilbert, 2003).

Toilet training adalah upaya pelatihan kontrol BAK dan BAB anak yang masing-masing dilakukan oleh sistem perkemihan dan defekasi. Seorang anak dikatakan sedang menjalani toilet training bila ia diajarkan untuk datang ke toilet saat ingin $\mathrm{BAK}$ atau $\mathrm{BAB}$, membuka pakaian 
seperlunya, melakukan miksi atau defekasi, membersihkan kembali dirinya, dan memakai kembali pakaian yang dilepaskan. Penguasaan anak terhadap kemampuan miksi dan defekasi terkontrol ini bisa simultan maupun berkala/bertahap. Kontrol perkemihan biasanya lebih mudah dilakukan pada siang hari, sedangkan pada malam hari sering terjadi kegagalan. Kegagalan ini akan terkompensasi setelah beberapa tahun. Toilet training dilakukan dalam dua minggu sampai dua bulan (Schmitt, 1991).

\section{Tujuan Toilet Training}

Tujuan dari pengajaran toilet training adalah mengajarkan kepada anak untuk mengontrol keinginannya ketika BAB atau BAK. Hal ini berhubungan dengan perkembangan sosial dan kepribadian anak di mana ia dituntut secara sosial untuk menjaga kebersihan diri dan melakukan BAB atau BAK pada tempatnya, yaitu toilet. (Feybi, 2007)

\section{Keuntungan Dilakukannya Toilet Training}

Toilet Training dapat menimbulkan kemampuan anak dalam mengontrol miksi dan defekasi. Seorang anak yang telah berhasil menjalani toilet training memiliki kemampuan menggunakan toilet pada saat ingin BAB atau BAK. Selain itu keuntungan pelaksanaan toilet training pada anak adalah:

a. Toilet training menjadi awal terbentuknya kemandirian anak secara nyata sebab anak sudah bisa melakukan sendiri hal-hal seperti BAB atau BAK.

b. Toilet training membuat anak dapat mengetahui bagian-bagian tubuh serta fungsinya.

\section{Mengajarkan Anak Cara Menggunakan Toilet}

Proses toilet training harus dilakukan dengan cara menawarkan bantuan, tetap sabar, dan menciptakan keadaan yang menyenangkan. Hindari timbulnya perasaan tertekan pada anak dan jangan berikan hukuman jika gagal. Anak harus merasakan dirinya mampu melakukan BAB atau BAK dan bisa mengendalikannya.

Pelaksanaan toilet training dilakukan teknik sebagai berikut: (a) Teknik lisan; (b) Teknik Modelling. Dalam memberikan contoh orangtua harus melakukannya dengan benar. Selain itu perlu diperhatikan ketepatan waktu 
saat memberikan contoh toilet training, serta mengkondusifkan suasana dengan memberikan pujian saat anak berhasil dan tidak marah saat anak gagal melakukan BAB atau BAK dengan benar.

http://hanababyshop.multiply.com/reviews/item/20 2010.

\section{Pedoman Toilet Training.}

Menurut Mahoney, 1971, tahapan yang akan dilalui anak dalam melakukan toilet training adalah sebagai berikut: (a) Mengenal tanda-tanda urgensi BAB atau BAK. (b)Bergerak dengan kesadaran sendiri menuju toilet. Menanggalkan pakaian secukupnya untuk membebaskan organ kemihnya. (d) Melakukan BAB atau BAK (e) Membersihkan diri dan menggunakan kembali pakaiannya.

\section{Faktor Pendukung Toilet Training}

Seorang anak mungkin akan kesulitan untuk memahami cara menggunakan perkakas toilet pada awal toilet training. Oleh karena itu, apabila dilakukan pengalihan dari penggunaan popok ke penggunaan toilet, terlebih dahulu dilakukan dengan alat bantu berupa toilet mini (Gilbert, 2003):

a. Peragakan cara penggunaan toilet.

b. Sesuaikan ukuran toilet.

c. Gunakan kursi toilet.

d. Jaga kebersihan.

e. Jangan paksakan pelatihan pada anak jika anak belum siap atau masih ketakutan menghadapi toilet.

Dalam rangka memudahkan anak untuk belajar, maka dibutuhkan beberapa intervensi.

Untuk pelaksanaan toilet training yang optimal maka diperlukan:

a. Membeli peralatan yang dibutuhkan

1) Kursi atau papan toilet yang digunakan untuk tempat naik dan menyangga kaki anak saat sedang BAB/BAK.

2) Makanan atau cemilan kesukaan anak untuk dijadikan hadiah atas keberhasilannya BAB atau BAK di toilet.

3) Diagram atau tabel pelaksanaan toilet training, serta penanda jumlah keberhasilan. 
b. Membuat posisi anak pada kursi toilet senyaman mungkin.

c. Rangsang anak untuk bergerak cepat menuju toilet jika memang aada tanda-tandanya.

d. Berikan selamat ataupun hadiah jika anak mampu menyelesaikan BAB atau BAK dengan baik.

e. Apabila anak gagal menuntaskan BAB atau BAK dengan baik sehingga celananya basah atau kotor, maka lakukan peringatan secara verbal dengan menggunakan kalimat yang suportif dan persuasif.

f. Apabila anak sudah mampu menggunakan toilet dengan baik secara kooperatif, penggunan popok bisa diganti dengan celana dalam.

Pelatihan dianggap sukses dan memadai jika anak telah mampu pergi ke toilet atas inisiatif sendiri dan mampu menyelesaikannya dengan baik. Pelatihan ini dilakukan selama 2 minggu sampai 2 bulan. Semakin lama pelatihan berlangsung, upaya 3 dan 4 dapat dikurangi (Schmitt, 1991).

\section{Faktor Penghambat Toilet Training}

Faktor yang menghambat pelatihan toilet adalah sebagai berikut:

a. Upaya toilet training dilakukan terlalu dini.

b. Orangtua telah menetapkan standar waktu pelaksanaan tanpa memperhatikan perkembangan anak.

c. Tekanan dari lingkungan atau orang lain untuk memaksakan pelatihan.

d. Orangtua atau pengasuh berpendapat bahwa anak harus mengalami toilet training sesegera mungkin untuk membuktikan keberhasilan pendidikan dan menunjukkan keunggulan si anak.

e. Perselisihan antara anak dan orangtua dalam menjalani toilet training.

f. Memberikan hukuman pada anak yang gagal dalam menyelesaikan proses $\mathrm{BAB}$ atau BAK di toilet dengan baik.

g. Adanya faktor stres pada kehidupan anak.

h. Adanya gangguan fisik atau organik pada anak, misalnya kerusakan sistem kemih ataupun sistem pencernaan sehingga menyebabkan gangguan fisiologis berkemih dan defekasi. Hal ini tampak apabila anak terlalu sering $\mathrm{BAB}$ atau $\mathrm{BAK}, \mathrm{BAB}$ atau $\mathrm{BAK}$ mengandung darah, ataupun nyeri saat berkemih atau defekasi. 
Sedangkan menurut DeBord (1997), penghambat dalam toilet training adalah sebagai berikut: (a) Memaksakan anak untuk duduk di toilet; (b) Bereaksi terlalu keras terhadap kesalahan anak; (c) Menggunakan obatobatan untuk mempercepat BAB atau BAK.

\section{Tanda-Tanda Kesiapan Anak Melakukan Toilet Training Sendiri}

Toilet training tidak boleh dilakukan sebelum anak siap. Kesiapan anak itu sendiri tergantung pada konsep dan kemampuan yang diajarkan sejak anak berusia 12 bulan. Salah satu stimulus yang sangat membantu adalah membacakan buku tentang usaha BAK atau BAB mandiri kepada anak. Toilet training dapat dimulai saat usia anak berkisar antara 18 sampai 30 bulan. Sebagian besar anak mulai toilet training pada usia 24 bulan, sebagian kecil pada 18 bulan. Pada usia 3 tahun, anak akan mampu belajar untuk toilet training sendiri tanpa bantuan.

Beberapa tahapan perkembangan kemampuan dan perubahan fisiologis anak dibutuhkan untuk toilet training. Hal tersebut antara lain (Gilbert, 2003):

a. Anak telah mampu menyadari bahwa pakaian atau popok yang digunakannya kotor atau basah. Hal ini mulai terjadi pada usia 15 bulan.

b. Anak telah mampu membedakan BAB dengan BAK, serta mampu memberitahukan kepada pengasuh bila mengalami urgensi $\mathrm{BAB}$ atau BAK. Hal ini mulai terjadi pada usia 18-24 bulan.

c. Anak mampu memberitahu terlebih dahulu jika ia ingin BAB atau BAK dalam interval waktu yang cukup untuk pengasuh mengantarkannya ke toilet.

d. Anak mampu melakukan kontrol terhadap kandung kemih dan mampu menahan keinginan BAB atau BAK selama beberapa saat.

\section{Cuci Tangan, Cuci Kaki dan Gosok Gigi Bagian dari Toilet Training}

Cuci tangan, cuci kaki dan gosok gigi merupakan bagian dari toilet training yang harus diajarkan pada anak. Kegiatan-kegiatan tersebut perlu diajarkan pada anak sejak dini agar anak bisa mandiri menjaga kebersihan dirinya sendiri. Mencuci tangan dan kaki setelah bermain atau BAB dan BAK akan menghindarkan anak dari kuman-kuman, bakteri, dan virus yang berbahaya bagi kesehatan anak. http://www.eurekaindonesia.org. 2008. 
Toilet Training Untuk Anak: Cuci Tangan.

Dengan mencuci tangan, penyebaran kuman-kuman yang ada di tangannya tadi dapat dicegah. Banyak penyakit antara lain influenza, diare, atau bahkan hepatitis A, dapat dicegah dengan cara sederhana seperti mencuci tangan. Namun bukan hanya sekedar mencuci tangan saja melainkan juga menggunakan sabun dan dilakukan di bawah air yang mengalir. Sabun memiliki kandungan basa dan itu bisa mengurangi atau melemahkan kuman yang ada di tangan. Semakin tinggi kadar basanya, semakin bagus juga kemampuannya untuk mengatasi kuman. Selain menggunakan sabun, hendaknya mencuci tangan juga dilakukan dengan air yang mengalir. Memang masih ada kebanyakan masyarakat yang menggunakan kobokan sebagai sarana untuk mencuci tangan sebelum makan. Untuk mengurangi penyebaran kuman-kuman di rumah anda biasakan mencuci tangan, terutama: (1) Sebelum makan dan masak, (2) Setelah menggunakan kamar mandi, (3) Setelah bersih-bersih di rumah. (4) Setelah menyentuh hewan, dll. Begitu juga dengan gosok gigi setelah bangun pagi dan sebelum tidur, akan menghindarkan anak dari kuman dan bakteri yang dapat merusak gigi anak. (http://kumpulan farmasi.blogspot.com/2010/11/pentingnya-mencuci-tangan. $\underline{h t m l}$

\section{B. Orang tua}

\section{Pengertian Orang Tua}

Orang tua adalah komponen keluarga yang terdiri dari ayah dan ibu, dan anak merupakan hasil dari sebuah ikatan perkawinan yang sah yang dapat membentuk sebuah keluarga. Orang tua memiliki tanggung jawab untuk mendidik, mengasuh dan membimbing anak-anaknya untuk mencapai tahapan tertentu yang menghantarkan anak untuk siap dalam kehidupan bermasyarakat.

\section{Peran Orang Tua Dalam Perkembangan Anak}

Pendidikan hendaknya dimulai sejak dini, sehingga tertanam kebiasaan dalam diri anak sejak kecil. Kebiasaan ini kelak akan menjadi kesadaran penuh saat anak telah mencapai usia akil baligh. 
Keluarga yang ideal (lengkap) maka ada dua individu yang memainkan peranan penting yaitu peran ayah dan peran ibu, secara umum peran kedua individu tersebut adalah :

a. Peran ibu adalah

1) memenuhi kebutuhan biologis dan fisik

2) merawat dan mengurus keluarga dengan sabar, mesra dan konsisten

3) mendidik, mengatur dan mengendalikan anak

4) menjadi contoh dan teladan bagi anak

b. Peran ayah adalah

1) ayah sebagai pencari nafkah

2) ayah sebagai suami yang penuh pengertian dan memberi rasa aman

3) ayah berpartisipasi dalam pendidikan anak

4) ayah sebagai pelindung atau tokoh yang tegas, bijaksana, mengasihi keluarga (http://bianobby.wordpress.com/)

\section{Peran Orang Tua Dalam Keluarga}

Keluarga merupakan kelompok sosial yang terdiri dari ayah, ibu dan anak. hubungan sosial diantara anggota keluarga relatif tetap dan didasarkan atas ikatan perkawinan, darah atau adopsi. Hubungan antara anggota keluarga dijiwai oleh suasana kasih sayang dan rasa tanggung jawab. Gupte, Suraj. 2004

Menurut Santrock, 2002 pengasuhan dalam keluarga mempunyai kebudayaan yang bervariasi, seperti apa peran ayah dan ibu, sejauh mana sistem-sistem bantuan diberikan kepada anak dan bagaimana anak-anak seharusnya didisiplinkan dalam berbagai hal termasuk dalam toilet training. Orang tua merupakan bagian keluarga besar yang sebagian besar telah tergantikan oleh keluarga inti yang terdiri dari ayah, ibu dan anak-anak. Secara tradisional, keluarga diartikan sebagai dua atau lebih orang yang dihubungkan dengan pertalian darah, perkawinan atau adopsi (hukum) yang memiliki tempat tinggal bersama. Keluarga merupakan suatu grup sosial primer yang didasarkan pada ikatan perkawinan (hubungan suami-istri) dan ikatan kekerabatan (hubungan antar generasi, orang tua-anak) sekaligus. Namun secara dinamis individu yang membentuk sebuah keluarga dapat digambarkan sebagai anggota dari grup masyarakat yang paling dasar yang tinggal bersama dan berinteraksi untuk memenuhi kebutuhan individu 
maupun antar individu mereka. Pendidikan di rumah merupakan tugas dan peran orangtua. Wiwien Dinar Pratisti (2008).

Keluarga dalam hubungannya dengan anak diidentikan sebagai tempat atau lembaga pengasuhan yang paling dapat memberi kasih sayang, kegiatan menyusui, dan memandirikan anak khususnya dalam toilet training. Pelatihan toilet bisa dilakukan secara rutin dengan melihat kesiapan anak dan tentunya kesabaran yang ekstra dari orangtua.

Di dalam keluargalah kali pertama anak-anak mendapat pengalaman dini langsung mengenai toilet training, yang akan digunakan sebagai bekal hidupnya dikemudian hari melalui latihan fisik, sosial, mental, emosional dan spritual. Karena anak ketika baru lahir tidak memiliki tata cara dan kebiasaan (budaya) yang begitu saja terjadi sendiri secara turun-temurun dari satu generasi ke generasi lain, oleh karena itu harus dikondisikan ke dalam suatu hubungan kebergantungan antara anak dengan agen lain (orang tua dan anggota keluarga lain) dan lingkungan yang mendukungnya baik dalam keluarga atau lingkungan yang lebih luas (masyarakat), selain faktor genetik berperan pula. Keikutsertaan keluarga dalam membantu setiap jenjang pendidikan anak merupakan sumber agen terpenting yang berfungsi meneruskan budaya melalui proses sosialisasi antara anak dengan lingkungannya dan keluarganya.Coughlin A.Pamela (2008)

Oleh karena itu, untuk mewujudkan satu fungsi tertentu bukan yang bersifat alami saja melainkan juga adanya berbagai faktor atau kekuatan yang ada di sekitar keluarga, seperti nilai-nilai, norma dan tingkah laku serta faktor-faktor lain yang ada di masyarakat. Sehingga di sini keluarga dapat dilihat juga sebagai subsistem dalam masyarakat (unit terkecil dalam masyarakat) yang saling berinteraksi dengan subsistem lainnya. Berjalannya fungsi dan peran keluarga dengan baik ditentukan oleh banyak faktor antara lain kestabilan keluarga. Dwi Hastuti, 2008.

Dari beberapa paparan pendapat di atas, dapat disimpulkan bahwa peran orang tua adalah fungsi yang dimainkan oleh orang tua dalam mendidik, mendisiplin, memandirikan anak yang berada pada posisi atau situasi tertentu dengan karakteristik atau kekhasan tertentu pula. 


\section{METODOLOGI PENELITIAN}

Penelitian ini menggunakan metode penelitian deskriptif yang memaparkan fenomena nyata yang terjadi di lokasi penelitian. Subjek dalam penelitian ini adalah: Orang tua dari anak yang berusia 2-3 tahun di Pontianak. Teknik Pengumpulan data dalam penelitian ini menggunakan angket yang diberikan kepada orangtua murid dan menggunakan wawancara. Wawancara ini menggunakan wawancara terstruktur dan tidak terstruktur.

Data yang dianalisis pada penelitian ini adalah data pada angket yang di isi oleh responden yakni orang tua mengenai pembiasaan penerapan toilet training pada anak. Metode analisis yang digunakan dalam penelitian ini adalah Analisis Deskriptif Persentase. Deskriptif persentase menurut peneliti ini diolah dengan cara frekuensi dibagi dengan jumlah responden dikali $100 \%$. Adapun rumusnya adalah sebagai berikut:

$$
P=\frac{f}{N} \times 100 \%
$$

Keterangan :

$\mathrm{P} \quad$ : Persentase

f : Frekuensi

$\mathrm{N}$ : Jumlah responde

100\% : Bilangan tetap. (Tanzeh, Ahmad dan Suyitno. 2006)

\section{HASIL DAN PEMBAHASAN}

Berdasarkan hasil analisis angket yang diberikan kepada orangtua tentang penerapan pembiasan toilet training pada anak berupa pengetahuan orangtua tentang pelaksanaan toilet training yang benar pada anaknya, tingkat keberhasilan orang tua dalam menerapkan toilet training pada anak usia 2-3 tahun di Pontianak dan faktor yang menyebabkan orangtua kurang melatih membiasakan anak untuk toilet training dengan benar pada anak usia 2-3 tahun di Pontianak.

Untuk menjawab semua aspek penelitian di atas, akan diuraikan di bawah ini. 1. Presentasi pengetahuan orangtua tentang pembiasaan toilet training yang benar kepada anak umur 2-3 tahun di Pontianak sebesar 60,98\%. Pengetahuan orangtua yang ditanyakan berupa bagaimana 
perkembangan anak usia 2-3 tahun tentang latihan toilet training, duduk di toilet, bereaksi ketika anak mau melakukan toilet training, yang dilakukan ketika anak susah $\mathrm{BAK}$ dan $\mathrm{BAB}$, menanggalkan sebagian baju ketika $\mathrm{BAB}$, dan kebersihan.

2. Tingkat keberhasilan orang tua dalam menerapkan toilet training pada anak usia 2-3 tahun di Pontianak sebesar 65,85\%. Dalam melihat tingkat keberhasilan ini peneliti juga memberikan wawancara langsung kepada beberapa orangtua dari anak yang berumur 2-3 tahun. Hal ini untuk memperkuat dari hasil angket yang diperoleh.

3. Faktor yang menyebabkan orangtua kurang melatih untuk membiasakan anak toilet training dengan benar pada anak usia 2-3 tahun di Pontianak adalah orangtua kurang mempunyai pengetahuan dan wawasan yang luas tentang perkembangan anak sehingga anak tidak dilaataih sesuai usia dan kemampuan anak, orangtua kurang sabar, orangtua kurang konsekwen dan orangtua kurang disiplin dalam menerapkan menerapkan toilet training pada anak.

Berikut grafik presentasi perolehan data yaitu submasalah nomor 1 dan submasalah nomor 2.

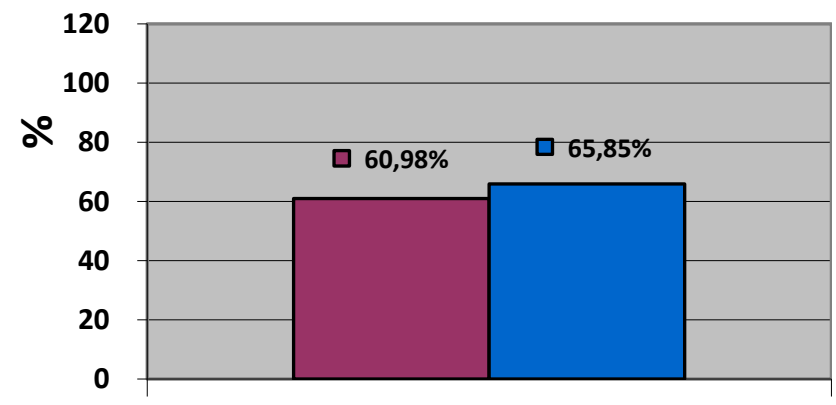

\section{SIMPULAN}

Berdasarkan uraian hasil analisis, pelaksanaan pembiasaan penerapan toilet traning pada anak usia 2-3 tahun di Pontianak dapat ditarik beberapa kesimpulan sebagai berikut. 
1. Presentasi pengetahuan orangtua tentang pembiasaan toilet training yang benar kepada anak umur 2-3 tahun di Pontianak sebesar 60,98\%.

2. Tingkat keberhasilan orang tua dalam menerapkan toilet training pada anak usia 2-3 tahun di Pontianak sebesar 65,85\%.

3. Faktor yang menyebabkan orangtua kurang melatih untuk membiasakan anak toilet training dengan benar pada anak usia 2-3 tahun di Pontianak. adalah orangtua kurang mempunyai pengetahuan dan wawasan yang luas tentang perkembangan anak sehingga anak tidak dilatih sesuai usia dan kemampuan anak, orangtua kurang sabar, orangtua kurang konsekwen dan orangtua kurang disiplin dalam menerapkan menerapkan toilet training pada anak.

\section{DAFTAR PUSTAKA}

Coughlin, Pamela. 2008. Creating Child-Centered Programs for Infanst and Toddlers, Washington, DC, Childrens Resources International. Inc Direktorat Jenderal Pendidikan Anak Usia Dini, Non Formal, dan Informal. 2011 Kementerian Pendidikan Nasional.

Feiby.2007. Pentingnya Memahami Perkembangan Si Kecil. Tabloid Nova Gilbert, Jane. (2003). Seri Panduan Praktis Keluarga Latihan Toilet. Jakarta:Erlangga.

Gupte, Suraj. 2004. Panduan Perawatan Anak. Jakarta: Pustaka Populer Obor

Hastuti, Dwi. 2008. Pengasuhan: Teori dan Prinsip Serta Aplikasinya di Indonesia. Bogor. Departemen Ilmu Keluarga dan Konsumen. Fakultas Ekologi Manusia. ITB.

Hurlock, E B.(2003).Psikologi Perkembangan Anak 2.Edisi kelima Jakarta:Erlangga

Santrock, John. Life-Span Development (Perkembangan Masa Hidup). Alih Bahasa Juda Damanik, Achmad Chusairi. Jakarta. PT. Airlangga.

Tanzeh, Ahmad dan Suyitno. 2006. Dasar-Dasar Penelitian. Surabaya : eLKAF.

Thompson, June. Penerjemah, Novita Jonathan. 2003. Toddlercare :Pedoman Merawat Balita. Jakarta : Erlangga 
Peraturan Menteri Pendidikan Nasional Republik Indonesia No.58 tahun 2009 tentang Standar Pendidikan Anak Usia Dini. Jakarta : Menteri Pendidikan

Pratisti, Wiwien Dinar (2008). Psikologi Anak Usia Dini, Jakarta: Indeks http://kumpulan-farmasi.blogspot.com/2010/11/pentingnya-mencucitangan.html

http://www.eurekaindonesia.org. 2008. Toilet Training Untuk Anak: Cuci Tangan.

http://hanababyshop.multiply.com/reviews/item/20 2010. Pedoman Toilet Training.

http://bianobby.wordpress.com. 